\title{
Evaluation of cognitive dysfunction syndrome in dogs using an observational questionnaire
}

\author{
Avaliação da síndrome de disfunção cognitiva em cães mediante o \\ uso de questionário observacional
}

\author{
Fernanda Dagmar Martins Krug1*; Mariana Teixeira Tillmann²; Martha Bravo \\ Cruz Piñeiro ${ }^{3}$; Sabrina de Oliveira Capella ${ }^{4}$; Aurélio Luciano Costa ${ }^{5}$; Fabio \\ Raphael Pascoti Bruhn ${ }^{6}$; Marcia de Oliveira Nobre ${ }^{6}$
}

\begin{abstract}
The life expectancy of dogs has increased in recent years, mainly due to intensified care by owners, through health care, nutrition, and wellness. Currently, we have a large population of elderly dogs and consequently, the development of age-related conditions, such as cognitive dysfunction syndrome (CDS). Thus, we aimed to identify signs compatible with canine CDS (CDS) in dogs, through investigation of daily behavioral changes. We collected data from review, interaction with other animals, and the behavior of dogs. An observational questionnaire was used to evaluate behavioral changes. The responses generated a summation of points for the classification of dogs with and without signs compatible with CCDS. We also evaluated the interference of behavioral changes in the cohabitation of the owner with his dog. Of the 178 dogs studied, 40 (22.4\%) had signs compatible with CCDS, especially those aged $\geq 10$ years $(31.4 \%)$. There were no statistical correlations with variables of sex, reproductive status, size, and race. Statistical differences were observed regarding the frequency of behavioral changes between dogs with and without CCDS in relation to disorientation, activity, sleep/wake cycle, house/ soil, and socioenvironmental interaction. The owners considered that dogs with CCDS alter their daily routine and were favorable to initiating treatment, although with reduced compliance for life-long medication. We conclude that dogs older than 10 years have signs compatible with CCDS regardless of race, sex, reproductive status, and size. They present changes mainly in behavior related to activity, socioenvironmental interaction, sleep/wake cycle, and house soil and, less frequently, the manifestation of disorientation.
\end{abstract}

Key words: Older dogs. Disorientation. Cognitive decline.

\section{Resumo}

A expectativa de vida dos cães tem aumentado nos últimos anos, principalmente pelos cuidados intensificados por parte dos tutores, através de cuidados com a saúde, nutrição e bem-estar. Hoje

\footnotetext{
Discente de Doutorado, Programa de Pós-Graduação em Veterinária, Universidade Federal de Pelotas, UFPel, Pelotas, RS, Brasil. E-mail: fernandadmkrug@gmail.com

2 Prof ${ }^{a}$, Universidade do Oeste Catarinense, UNOESC, Xanxerê, SC, Brasil. E-mail: mariana.teixeira.tillmann@gmail.com

3 Discente de Mestrado, Programa de Pós-Graduação em Veterinária, UFPel, Pelotas, RS, Brasil. E-mail: martha.pineiro@hotmail. com

4 Dr ${ }^{\mathrm{a}}$ em Ciências, UFPel, Pelotas, RS, Brasil. E-mail: capellas.oliveira@gmail.com

5 M.e em Ciências, UFPel, Pelotas, RS, Brasil. E-mail: aurelio_ena@hotmail.com

6 Profs., UFPel, Pelotas, RS, Brasil., E-mail: fabio_rpb@yahoo.com.br; marciaonobre@gmail.com

* Author for correspondence
} 
temos uma grande população de cães idosos e consequentemente o desenvolvimento de afecções ligadas à idade, como a síndrome de disfunção cognitiva (SDCC). Assim objetivou-se identificar sinais compatíveis com síndrome de disfunção cognitiva em cães, através da investigação das alterações comportamentais cotidianas. Primeiramente foram coletados dados de resenha, convívio com outros animais e o comportamento dos cães. Foi utilizado questionário observacional avaliando alterações comportamentais. As respostas geraram um somatório de pontos para classificação dos cães com e sem sinais compatíveis com disfunção cognitiva. Também foi avaliada a interferência das alterações comportamentais na convivência do tutor com o seu cão. Dos 178 cães estudados $40(22,4 \%)$ apresentaram sinais compatíveis com SDCC, principalmente cães com idade igual ou superior a 10 anos (31,4\%). Não foram observadas associações estatísticas $(\mathrm{p}>0,005)$ com as variáveis independentes sexo, estado reprodutivo, porte e raça dos cães. Foram observadas diferenças estatísticas $(\mathrm{p}<0,05)$ em relação à frequência de alterações comportamentais, entre os cães com e sem SDCC, em relação â desorientação, atividade, ciclo sono/vigília, casa/sujidade e interação socioambiental. Os tutores consideraram que os cães com SDCC alteram a sua rotina diária, sendo favoráveis a iniciar o tratamento, embora com menor adesão quando se refere a medicação por toda vida. Conclui-se que, cães com mais de dez anos apresentam sinais compatíveis com SDCC, independentemente da raça, sexo, estado reprodutivo e porte. Esses animais apresentaram alterações no comportamento principalmente ligados a atividade, interação socioambiental, ciclo sono/vigília e casa/sujidade e com menor frequência a manifestação de desorientação.

Palavras-chave: Cães idosos. Desorientação. Declínio cognitivo.

\section{Introduction}

The increase in canine life expectancy is the result of a better knowledge of their health, nutritional quality, sanitary control, diagnosis, and effective treatments (LANDSBERG; ARAUJO, 2005). This reality has resulted in the need to diagnose and intervene earlier in diseases related to senility because with the increase of age, the disorders related to cognition become more frequent (PÉREZ-GUISADO, 2007). With the increase of a dog's age, neurobehavioral alterations related to consciousness, perception, memory, and learning begin to occur resulting in a decline in the cognitive and behavioral capacity, known as canine cognitive dysfunction syndrome (CCDS) (SIWAK, 2002; LANDSBERG; ARAUJO, 2005; OSELLA et al., 2007; GONZÁLEZ-MARTÍNEZ etal., 2012). These cognitive changes can be obtained from owners using observational questionnaires and classified into categories named through the acronym DISHA (Desorientation, Interactions, Sleep, Housetraining, Activity) (NEILSON et al., 2001; LANDSBERG et al., 2008; OSELLA et al., 2007). The presence or absence of CCDS is determined by the sum of the scores obtained from the owner's answers regarding the behavioral changes of a dog (ROFINA et al., 2006; FAST et al., 2013).

CCDS, which is similar to Alzheimer's disease that affects humans (PÉREZ-GUISADO, 2007), increasingly urges the research community to conduct more research studies. It is important to develop studies that enable early diagnosis allowing a better quality of life for the elderly dogs and preparing the owner to provide the necessary care for the $\operatorname{dog}$ with CCDS. Since currently, a definitive diagnosis of CCDS is only possible post-mortem, it is extremely important to look for ways to identify the behavioral changes of this syndrome in advance; therefore, a clinical diagnosis can be performed allowing an early and appropriate therapy to reduce the progression of CCDS, because there is no curative therapy so far (PÉREZ-GUISADO, 2007). Therefore, one of the alternatives for the detection and screening of the first cognitive alterations are the observational questionnaires (SCHÜTT et al., 2015). Similar to humans with Alzheimer's disease, observational questionnaires adapted for use in animals are sensitive and effective tools for the 
identification of cognitive impairment in elderly dogs (LANDSBERG et al., 2012; SALVIN et al., 2011; MALEK-AHMADI et al., 2012).

Therefore, we aimed to identify signs compatible with cognitive dysfunction syndrome in dogs, through the investigation of daily behavioral changes related to this syndrome.

\section{Material and Methods}

An online observation questionnaire was available to owners of dogs over seven years of age. The questionnaire for the evaluation of cognitive disorders in dogs was adapted for some behavioral questions from Osella et al. (2007) and RNG (2012). The observational questionnaire was made available on a digital platform and widely distributed throughout Brazil. This research was approved by the ethics committee on animal experimentation (number 4655-2015).

The first part of the questionnaire was related to a dog review, such as age ( 7 to 9 years or $\geq 10$ years), gender (male or female), race (with or without breed), size (small, medium, or large), reproductive status (whole or castrated/spayed), place of residence (home with or without yard) and coexistence with other animals (yes or no). The owner's impression of the behavior of the dog in relation to fear/ anxiety/ aggressiveness and/or tranquility (Table 1) was also investigated. Regarding the evaluation of the dog behavior, the questions were divided into categories of disorientation, socioenvironmental interaction, sleep-wake cycle, evacuation site, and activity. Regarding "disorientation" the behavioral parameters were: being lost in familiar places, stopping in the opposite corner of an opening door when leaving, and crashing instead of avoiding obstacles. In relation to "activity", it was sought to identify if the dog was restless all the time, more tearful when left at home alone, vocalized beyond usual, presented changes of appetite and water intake, wander endlessly without an apparent purpose, stopped responding when called, refused to walk or play, stared into empty space. In the "sleep/wake cycle", it was investigated whether the animal presented himself restlessness during sleep or if he slept more often during the day. In the "evacuation site" category, the questions were about eliminating excreta (evacuating or urinating) in inappropriate places. Regarding the "socialenvironmental interaction", we evaluated if the animal showed less interest in contact/affection, stopped greeting when someone arrived, seemed always irritated, had difficulty recognizing familiar people or animals, quarreled or avoided contact with other animals, presented changes regarding caring for own hygiene, and lost self-control in stressful situations. The answers to these questions were: never, infrequently, often, and always, with scores 1, 2, 3, and 5, respectively, indicating that the higher the score the more severe the changes were. In this way, the sum of all questions was completed, with each dog questionnaire ranging from 25 to 125 points (RNG, 2012). For the development of this study, dogs with a sum of 50 points or more were considered with compatible signs of CCDS and scores up to 49 were classified as without signs compatible with CCDS. We also investigated the position of the owner regarding the dog treatment and daily routine of caring that is modified with behavioral changes (Table 1). 
Table 1. Demonstration of the review data of the dogs studied with signs compatible with CCDS (Canine Cognitive Dysfunction Syndrome) and without signs, performed in the city of Pelotas, RS, between 2015 and 2016.

\begin{tabular}{llll}
\hline \multirow{2}{*}{ Parameters analyzed } & $\begin{array}{l}\text { Dogs with no signs of CCDS } \\
\text { n (\%) }\end{array}$ & $\begin{array}{l}\text { Dogs with signs of CCDS } \\
\text { n (\%) }\end{array}$ \\
\hline \multirow{2}{*}{ Age } & Less than 9 years & $79(85.9)$ & $13(14.1)$ \\
& 10 years or more* & $59(68.6)$ & $27(31.4)$ \\
\hline \multirow{2}{*}{ Gender } & Female & $86(76.8)$ & $26(23.2)$ \\
& Male & $52(78.8)$ & $14(21.2)$ \\
\hline \multirow{2}{*}{ Breed } & Dog with defined breed & $83(74.8)$ & $28(25.2)$ \\
& Mixed breed dog & $55(81.1)$ & $12(17.9)$ \\
\multirow{2}{*}{ Size } & Small size & $72(75.8)$ & $23(24.2)$ \\
& Midsize & $40(75.5)$ & $13(24.5)$ \\
\hline \multirow{2}{*}{$\begin{array}{l}\text { Reproductive } \\
\text { Status }\end{array}$} & Large & $26(86.7)$ & $4(13.3)$ \\
& Whole female & $42(82.4)$ & $9(17.6)$ \\
\hline \multirow{2}{*}{ Dwelling } & Whayed female & $44(72.1)$ & $17(27.9)$ \\
\hline Living with other male & Yes & $41(74.5)$ & $14(25.5)$ \\
animals & With yard & $11(100)$ & --- \\
\hline \multirow{2}{*}{ Behavior } & Without yard & $108(77.7)$ & $31(22.3)$ \\
& Calm & $30(76.9)$ & $9(23.1)$ \\
\hline
\end{tabular}

The SPSS 20.0 software was used to perform all the statistical analysis. To evaluate the association between parameters related to changes in dog behavior (never/rarely or often/always) and review (independent variables) with the occurrence of CCDS in the animals (yes or no), chi-square tests or Fisher's exact, when less than five observations were observed in at least one of the boxes in the test contingency table. As a risk measure, the odds ratios and corresponding $95 \%$ confidence intervals $(95 \%$ CI) were calculated for each statistical association verified. A minimum confidence level of $95 \%$ was considered in all statistical analysis.

\section{Results and Discussion}

We obtained responses from 178 questionnaires, of which $150(84.26 \%)$ were from Rio Grande do
Sul, 12 (6.74\%) from Santa Catarina, 8 (4.5\%) from Paraná, and 8 (4.5\%) from Sao Paulo. The study showed that $40 / 178(22.4 \%)$ of the adult/mature dogs had more than 50 points in the observational questionnaire and were considered to show CCDS signs (Table 1). The prevalence of CCDS in dogs is between $14 \%$ and $35 \%$ in the elderly, although the disease is considered underdiagnosed (SALVIN et al., 2011; GONZÁLEZ-MARTÍNEZ et al., 2012). This is because most veterinary clinicians do not have the habit of screening these alterations and the owner considers these changes within the normality of aging. In a recent study, using an observational questionnaire, it was observed that there is a prevalence of behavioral changes in the canine population varying from $22.3 \%$ to $90.7 \%$, with six and one category of altered behavioral change (SVICERO et al., 2017). 
Statistical differences $(\mathrm{p}<0.05)$ were observed in relation to the frequency of behavioral changes between dogs with and without CCDS, in relation to disorientation, activity, sleep/wake cycle, evacuation site, and socioenvironmental interaction (Table 2). The dogs (Table 1) were aged between 7 and 19 years (92 dogs $\leq 9$ years old and 86 dogs $\geq 10$ years old, 66 males and 112 females). Regarding their breed, 111 had a defined breed (Poodle, ShihTzu, Pinscher, Dachshund, Labrador, Golden Retriever, Beagle, York Shire, Danish, Cocker, and Pitt Bull) and 67 were undefined; of these, 95 were small; 53, medium; and 30, large. Regarding the reproductive condition, 55 males and 51 females were whole and 11 males and 61 females were castrated. The dogs' housings were predominantly home with yard (139) while the minority lived at home without yard or in an apartment (39); 146 dogs lived with other animals and 32 lived only with humans. The owners identified that 72 of the studied dogs demonstrated fear/anxiety/aggressiveness while 106 dogs were considered quiet.

CCDS signs were more frequent in dogs with $\geq 10$ years of age $(31.4 \%)$ when compared to dogs with $\leq 9$ years $(17.90 \%)(p<0.006)$. In the present study, it was observed that an increase in canine age increased the probability of developing changes in cognition (NEILSON et al., 2001; AZKONA et al., 2009; KATINA et al., 2016; SVICERO et al., 2017). As the number of mature and elderly adult dogs increases (AKZONA et al., 2009), it is becoming essential to perform a cognitive evaluation of these dogs, as part of a clinical routine, since longevity cannot be considered proportional to quality of life (KATINA et al, 2016).

The first clinical signs, such as disorientation, elimination of excreta in inappropriate places, and decrease of the interaction with the owner appear from the age of seven, becoming more accentuated from the age of 11 (GREER et al., 2007; PÉREZGUISADO, 2007). It is important to note that aging leads to a decline in cognitive status and predisposes behavioral changes (LANDSBERG et al., 2008; LANDSBERG; ARAUJO, 2005). This was also demonstrated in clinical studies conducted in Brazil, Spain, and Turkey, where the dogs studied had more evident and serious signs of CCDS as the age increased (BENNETT, 2012; GALLEGO et al., 2010; SVICERO et al., 2017).

Regarding other parameters of the animal review, no statistical differences were demonstrated between dogs with and without compatible CCDS signs (Table 1). The research carried out tends to show that there is no predilection for breed, sex, reproductive status, and size (ROFINA et al., 2006; FAST et al., 2013; SVICERO et al., 2017). As well as a higher risk factor for male dogs to develop CCDS (SVICERO et al., 2017). A higher frequency of signs of cognitive dysfunction syndrome has been observed in females and castrated males, possibly because of alterations in sex hormones, since progesterone and testosterone are considered neuroprotective (LANDSBERG; ARAUJO, 2005; AZKONA et al., 2009) preventing, thus, neurodegeneration. Researchers point out that castrated canine females are predisposed to develop cognitive alterations, similar to those seen in women whose Alzheimer's disease is related to menopausal years, because of a decrease in the levels of sex hormones, estrogen and progesterone (AZKONA et al. 2009; SVICERO et al., 2017).

According to the perception of the owners, in the group of dogs with CCDS, fear, anxiety, and/or aggressiveness $(30.60 \%)$ were more frequent than a calm behavior $(17 \%)(p<0.033)$. The responses to the observational questionnaire revealed significant behavioral changes in dogs with CCDS compared to dogs without CCDS (Table 2). Among the most frequent parameters found in dogs with CCDS were sleeping more during the day (85\%), weeping when left home alone $(70 \%)$ and the need of constant contact (62.5\%). In a study with 84 dogs older than 8 years of age, the most frequent alterations were in relation to sleeping during the day and being restless at night, decreased interaction, disorientation, and anxiety (FAST et al., 2013) 


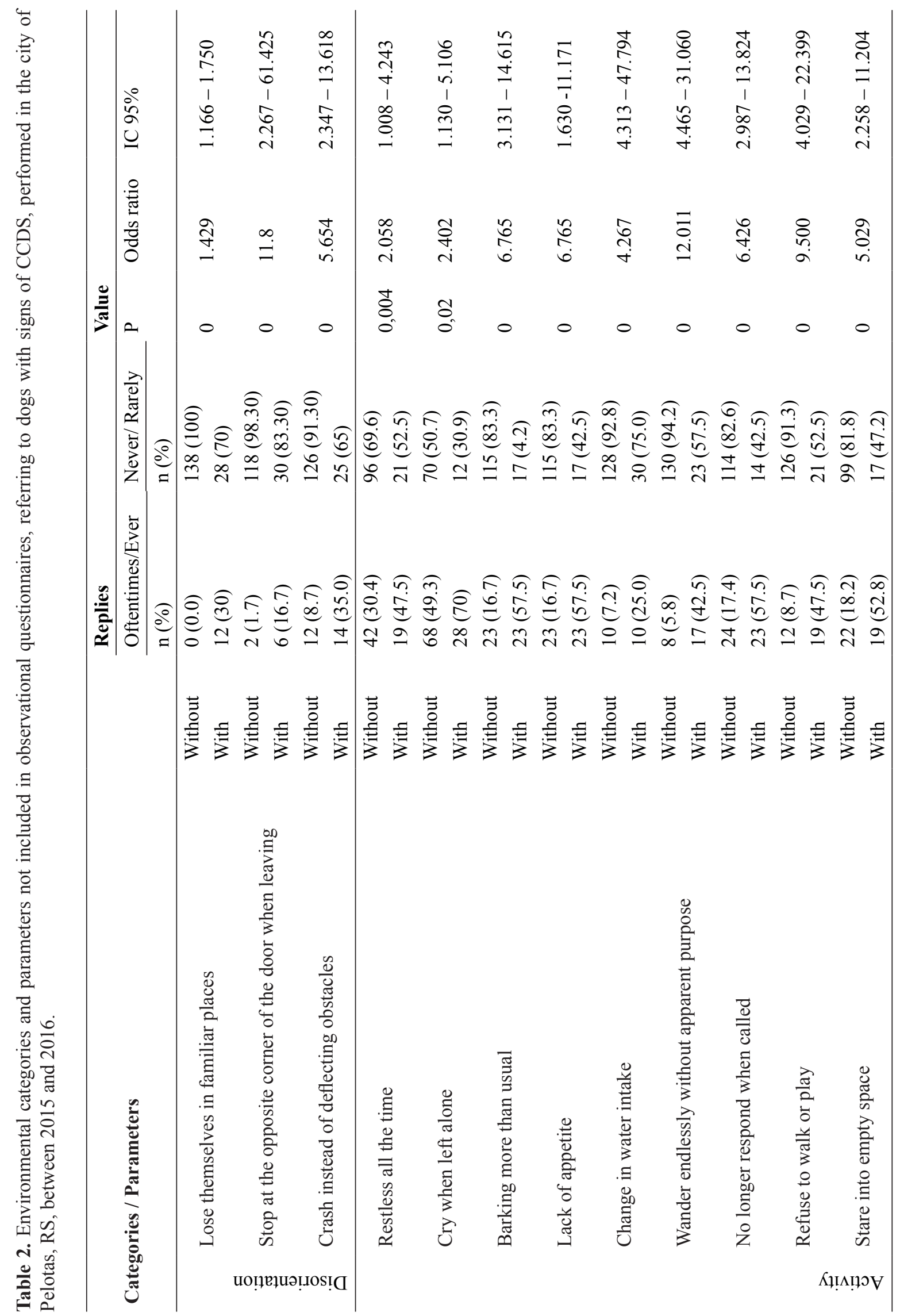




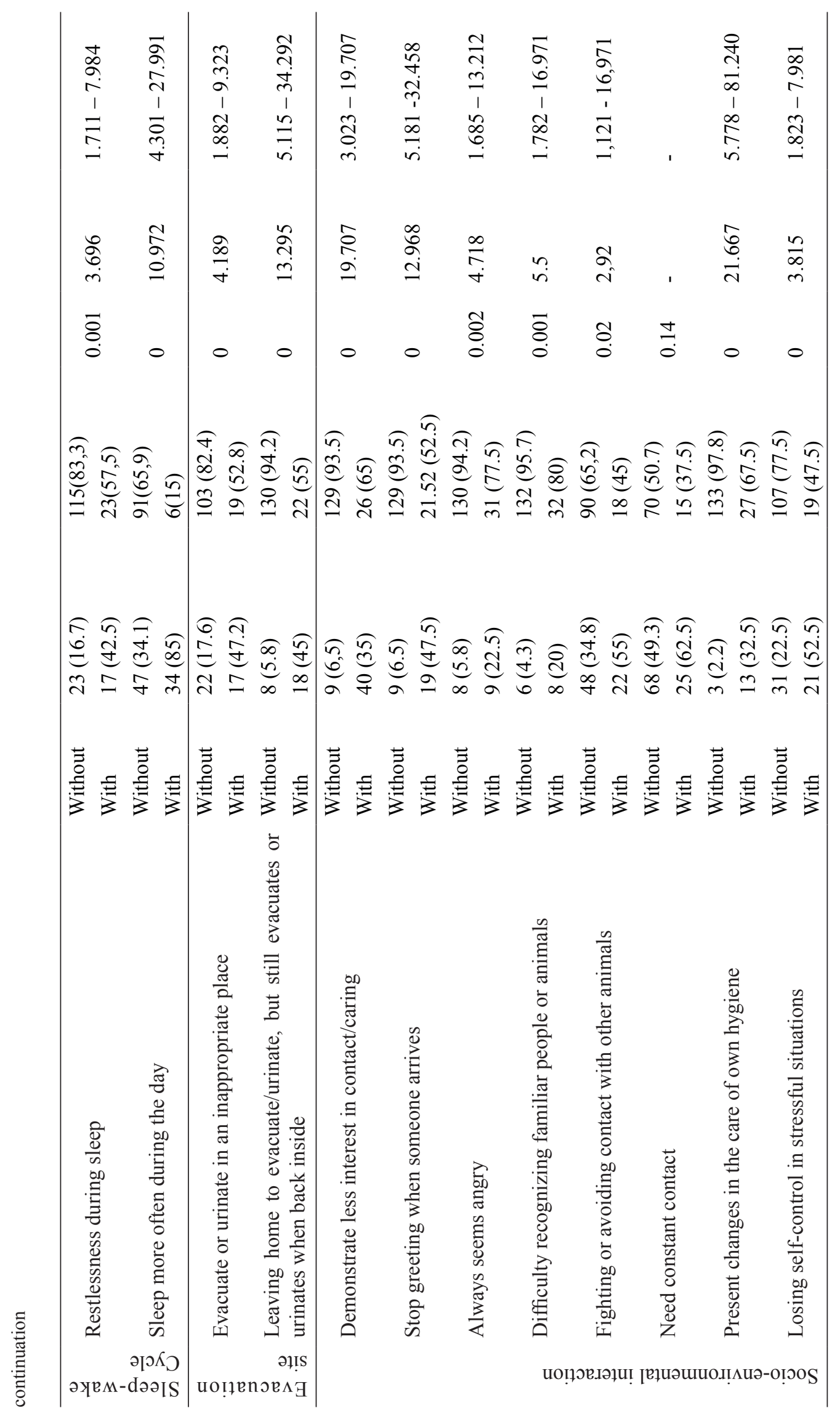


Other important behavioral changes that occurred in more than $50 \%$ of dogs with CCDS were: failure to respond when called $(57.5 \%)$, barking more than usual (57.5\%), altered appetite and water (57.5\%), fighting or avoiding contact with other animals (55\%), vacant eyes $(52.8 \%)$, and losing self-control in stress situations (52.5\%) (Table 2). The behavioral changes with higher frequency index occurred mainly in the categories of activity, sleep/wake cycle, evacuation site, and socio-environmental interaction. These findings were verified by other studies that used observational questionnaires as a tool to investigate behavioral alterations (AZKONA et al., 2009; FAST et al., 2013). In the parameters included in the disorientation category, there was a lower frequency of behavioral changes, possibly due to the more advanced stage of the canine cognitive dysfunction syndrome. This lower frequency was also observed by Marcolino et al., 2016. It is still important to emphasize that cognitive disorders are progressive. As soon as an animal manifests a change in behavior, it is expected that new behavioral changes will be manifested within a period of 6 to 18 months in other categories studied in this article (BAIN, 2001; FAST et al., 2016). It has already been demonstrated that the manifestations of cognitive alterations vary according to the severity of the cognitive impairment. Among the categories discussed in this article, changes in social interaction are observed mainly in animals with mild to moderate changes, and as the condition becomes more severe, there are manifestations in the other categories, such as a decrease in curiosity behaviors, making it difficult to find food, (1) and (2), and (2) the behavior of non-locomotion, being trapped behind objects and culminating with the difficulty of recognizing the owner (SALVIN et al., 2011; ROSADO et al., 2012; MADARI et al., 2015).

The aging of dogs occurs, similarly to the aging of humans, with the development of several cerebral changes that include cortical atrophy, thickening and calcification of the meninges, dilation of the ventricles, enlargement of the grooves and retraction of the convolutions, and glial reactivity (GONZÁLEZ-MARTÍNEZ et al., 2012). The behavioral changes related to CCDS syndrome occur because of neurodegeneration, with the development of senile plaques, which are agglomerates of plaque-forming amyloid beta protein, in several regions of the prefrontal cortex, hippocampus, and cerebellum (HEAD, 2001; FAST et al., 2013; PINEDA, 2014). Although it is not yet clear how senile plaques influence the cognition of these patients, it is known that this peptide has neurotoxic properties that compromise neuronal function, causing synapse degeneration, neuronal death, and neurotransmitter depression (GONZÁLEZ-MARTÍNEZ et al., 2012). Despite the similarity of CCDS to Alzheimer's disease in humans, senile plaques present themselves differently in both species. In dogs, the amyloid beta-protein deposition is diffusely present and does not form neurofibrillary tangles, as occurs in humans affected by Alzheimer's disease (CASTAÑEDA, 2015). This difference may be related to the time of development of the senile plaques, meaning that even with the increase in canine longevity in the last years, the canine life expectancy is much lower than the human life expectancy (PINEDA, 2014). The extent of amyloid beta-protein deposition, along with oxidative damage, is directly linked to the development and progression of clinical signs of CCDS (GONZÁLEZ-MARTÍNEZ et al., 2012).

Caring for a dog with CCDS changes the daily routine of the owners $(p=0.000)$ when compared to the care of a healthy dog. This is due to the high frequency of behaviors that require specific care, as well as to the fact that dogs that are affected gradually lose their hygiene habits, activity, and interaction with family members and other animals (BOWEN; HEATH, 2005). Even so, the owners demonstrated that they were favorable to initiate drug, nutritional, and environmental treatments to improve the quality of life of elderly $\operatorname{dogs}(p=0.07)$, although this affirmation was reduced when referring to lifelong 
treatment (Table 2). Therefore, it is important that the veterinarian has the knowledge to guide owners with the adequate management of a dog with cognitive dysfunction syndrome, so that the quality of life is maintained, avoiding the progression of the syndrome with the use of drug therapy, nutritional therapy, and environmental enrichment.

There are studies that have correlated observational questionnaires developed from different strategies, but extremely effective in the identification of CCDS (SCHÜTT et al., 2012). The observational questionnaire is an important tool for the early diagnosis of CCDS that can be easily applied in the clinical routine (ROFINA et al., 2006; CORY, 2013). These questionnaires allow the clinician to evaluate the existence of clinical signs compatible with CCDS, which often go unnoticed or are considered irrelevant by the owners since they are considered a normal part of dog aging (GONZÁLEZ-MARTÍNEZ et al., 2012). The use of the observational questionnaire facilitates identification of behavioral changes and indicates the presence of cognitive alterations. It is necessary to evaluate fully an elderly dog for any signs of behavioral change, since the diagnosis of CCDS is performed by exclusion of several diseases, which are included for differential diagnosis. There are several tools that can help with the diagnosis, including clinical and neurological evaluation, complementary exams with hematological and metabolic analysis as well as imaging (tomography/ magnetic resonance imaging) and cognitive tests (LANDSBERG; ARAUJO, 2005; GONZÁLEZMARTÍNEZ et al., 2012; BENNETT, 2012; SVISCERO et al, 2017). Cognitive tests are easily applicable in the clinical routine and evaluate the interaction, behavior, and social interaction of animals, with tests such as the open field, curiosity, interaction with humans and the use of objects such as mirrors (MARTÍNEZ et al., 2013).

The diagnosis of CCDS allows early treatment, improvement of quality of life of dogs and the relationship of the dog with their owner. It has been shown that dogs with CCDS can have the score of the observational questionnaire decreased after a few months of treatment taking into account supportive care, medications (selegeline), specific diets, general health control, and the use of stimulant toys of cognition (FAST et al., 2013).

\section{Conclusion}

It was concluded that dogs over 10 years of age presented behavioral changes regarding their learning, the environment, the state of sleep and wakefulness, as well as changes in the evacuation site, and they may be carriers of cognitive dysfunction syndrome.

\section{References}

AZKONA, G.; GARCÍA-BEKENGUER, S.; CHACÓN, G.; ROSADO, B.; LÉON, M.; PALACIO, J. Prevalence and risk factores behavioural changes associated with age-related cognitive impairment in geriatric dogs. Journal of Small Animal Pratice, v. 50, n. 2, p. 87-91, 2009. DOI: $10.1111 /$ j.1748-5827.2008.00718.x

BAIN, M. J. Predicting behavioral changes associated with age related cognitive impairment in dogs. Journal of the American Veterinary Medical Association, Califórnia, v. 218, n. 11, p. 1792-1795, 2001. DOI: 10.2460/javma.2001.218.1792

BENNETT, S. Cognitive dysfunction in dogs: Pathologic neurodegeneration or just growing older? The Veterinary Journal, Londres, v. 194, n. 2, p. 141-142, 2012. DOI: 10.1016/j.tvj1.2012.05.009

BOWEN, J.; HEATH, S. Geriatric behavioural issues. In: BOWEN, J.; HEATH, S. Behaviour problems in small animals. Philadelphia: Elsevier Limited. 2005. p. 59-69.

CASTAÑEDA, I. G. Metodos diagnósticos para la determinación de la disfunción cognoscitiva en perros geriatras (SDC Parte 2). Revista Vanguardia Veterinaria, v. 68 , n. 2 , p. $34-47,2015$. Available in: https://www. researchgate.net/publication/318947716_. Acess at: 15 mar. 2015

CORY, J. Identification and management of cognitive decline in companion animals and the comparisons with Alzheimer disease: a review. Journal of Veterinary Behavior, Brandon, v. 8, n. 4, p. 291-301, 2013. DOI: 10.1016/j.jveb.2012.08.001 
FAST，R.; SCHÜTT, T.; TOFT, N.; MOLLER, A.; BERENDT, A. N. D. M. An observational study with long-term follow-up of canine cognitive dysfunction: clinical characteristics, survival, and risk factors. Journal of Veterinary Internal Medicine, Copenhagen, v. 27, n. 4, p. 822-829, 2013. DOI: 10.1111/jvim.12109

GALlEGO, D. V.; FIGUEROA, J. R.; OROZCO, C. S. Síndrome de disfuncíon cognitiva de perros geriátricos. Revista MVZ Córdoba, Córdoba, v. 15, n. 3, p. 22522262, 2010. DOI: http://sci- 10.21897/rmvz.313

GREER, K. A.; CANTERBERRY, S. C.; MURPHY, K. E. Statistical analysis regarding the effects of height and weight on life span of the domestic dog. Research in Veterinary Science, Texas, v. 82, n. 2, p. 208-214, 2007. DOI: 10.1016/j.rvsc.2006.06.005

GONZÁLEZ-MARTÍNEZ, A.; ROSADO, B.; GARCÍABELENGUER, S.; GARCÍA-BELENGUER, S. Síndrome de disfunción cognitiva en el perro geriátrico. Clínica Veterinaria de Pequeños Animales, Zaragoza, v. 32, n. 3, p. 159-167, 2012. DOI: https://ddd.uab.cat/ record/130189

HEAD, E. B. Aging in dogs: parallels with human brain aging and Alzheimer's disease. Veterinary therapeutics, California, v. 2, n. 3, p. 247-260, 2001. Available in: https://www.ncbi.nlm.nih.gov/ pubmed/19746668

Acess at: 15 mar. 2015

KATINA, S.; FARBAKOVA, J.; MADARI, A. Risk factors for canine cognitive. Acta Veterinaria Scandinavica, Kotlarska, v. 58, n. 17, p. 2-7, 2016. DOI: 10.11862s13028-016-0196-5

LANDSBERG, G.; ARAUJO, A. Behavior Problems in Geriatric Pets. Veterinary Clinics of North America: Small Animal Practice, v. 35, n. 3, p. 675-698, 2005. DOI: $10.1016 /$ j.cvsm.2004.12.008

LANDSBERG, G. M.; NICHOL, J.; ARAUJO, J. A. Cognitive dysfunction syndrome: a disease of canine and feline brain aging. Veterinary Clinics of North America: Small Animal Practice, v. 42, n. 4, p. 749-768, 2012. DOI: $10.1016 /$ j.cvsm.2012.04.003

LANDSBERG, G. M.; SHERMAN, B. L.; ZIMMERMAN, A.; MELESE, P.; NEILSON, J. C.; CLARCK, T.P. Effectiveness of fluoxetine chewable tablets in the treatment of canine separation anxiety. Journal of Veterinary Behavior Clinical Applicationsand Research, v. 3, n. 1, p. 12-19, 2008. DOI: 10.1016/j. jveb.2007.09.001

MADARI, A.; FARBAKOVA, J.; KATINA, S. Assessment of severity and progression of canine cognitive dysfunction syndrome using the canine dementia scale (cades). Aplied Animal Behavior Science, v. 171, n. 1, p. 138-145, 2015. DOI: 1016/j. applanim.2015.08.034

MARCOLINO, G.; ESCODRO, P. B.; SOUZA, F.W.; NOTOM, M. K. Utilização de formulário clínico para reconhecimento de distúrbio cognitivo em cães idosos. Revista Ciência Veterinária nos Trópicos, Recife, v 19, n. 2. p. 10-18, 2016. Available in: http://www.rcvt.org. br/volume19_2/Revista\%20Cient\%C3\% ADfica2.pdf. Acess at: 15 mar. 2015

MARTÍNEZ, A. G; ROSADO, B.; PESINI, P.; GARCÍABELENGUER, S.; PALACIO, J.; VILLEGAS, A.; SUÁREZ, M. L.; SANTAMARINA, G.; SARASA, M.. Effect of age and severity of cognitive dysfunction on two simple tasks in pet dogs. The Veterinary Journal, Lugo, v. 198, n. 1, p. 176-181, 2013. DOI: 10.1016/j. tvj1.2013.07.004

MALEK-AHMADI, M.; DAVIS, K.; BELDEN, C.; LAIZURE, B.; JACOBSON, S.; YAARI, R.; SINGH, U.; SABBAGH, M.N. Validation and diagnostic accuracy of the Alzheimer's questionnaire. Age Ageing, Sun City, v. 41, n. 3, p. 396-399, 2012. DOI: 10.1093/ageing/afs008

NEILSON, J. C.; HART, B. L.; CLIFF, K. D.; RUEHL, W. W. Prevalence of behavioral changes associated with age-related cognitive impairment in dogs. Journal of the American Veterinary Medical Association, Portland, v. 18, n. 11, p. 1787-1791, 2001. DOI: 10.2460/ javma.2001.218.1787

OSELLA, M.; RE, G.; ODORE, R.; GIRARDI, C.; BADINO, P.; BARBERO, R.; BERGAMASCO, L. Canine cognitive dysfunction syndrome: prevalence, clinical signs and treatment with a neuroprotective nutraceutical. Applied Animal Behaviour Science, Grugliasco, v. 105, n. 4, p. 297-310, 2007. DOI: 10.1016/j.applanim.2006.11.007

PÉREZ-GUISADO, J. El Síndrome de disfuncíon cognitiva en el perro. Revista Electrónica de Clínica Veterinária RECVET, Lugo, v. 2, n. 1, p. 1-9, 2007.

PINEDA, S.; OLIVARES, A.; MAS, B.; IBAÑEZ, M. Cognitive dysfunction syndrome: updated behavioral and clinical evaluations as a tool to evaluate the wellbeing of aging dogs. Archivos de Medicina Veterinaria, Madrid, v. 46, n. 1, p. 1-12, 2014. DOI: 10.4067/S0301$732 \times 2014000100002$

REGENERATIVE NEUROSCIENCE GROUP - RNG. Canine-cognitive-dysfunction-rating-scale-CCDR. 2012. Available in: http://www.surveygizmo.com/s3/1839821/ Canine-Cognitive-Dysfunction-Rating-scale-CCDR. Acess at: 20 mar. 2015. 
ROFINA, J. E.; VAN EDEREN, A. M.; TOUSSAINT, M. J. M.; SECRÈVE, M.; VAN DER SPEK, A.; VAN DER MEER, I.; VAN EERDENBURG, F. J. C. M.; GRUYS, E. Cognitive disturbances in old dogs suffering from the canine counterpart of Alzheimer's disease. Brain Research, v. 1069, n. 1, p. 216-226, 2006. DOI: 10.1016/j.brainres.2005.11.021

ROSADO, B.; MARTÍNEZ, A. G.; PESINI, P.; GARCIA, B. S.; PALACIO, J.; VILlEGAS, A.; SUÁREZ, M.L; SANTAMARINA, G.; SARASA, M. Effect of age and severity of cognitive dysfunction on spontaneous activity in pet dogs - Part 1: locomotor and exploratory behaviour. The Veterinar Journal, Zaragoza, v. 194, n. 2, p. 189-195, 2012. DOI: 10.1016/j.tvj1.2012.03.025

SALVIN, H. E.; MCGREEVY, P.D.; SACHDEV, P. S. The canine cognitive dysfunction rating scale (CCDR):
A data-driven and ecologically relevant assessment tool. The Veterinary Journal, Sydney, v. 188, n. 3, p. 331-336, 2011. DOI: 10.1016/j.tvj1.2010.05.014

SCHÜTT, T.; TOFT, N.; BERENDT, M. A comparison of two screening questionnaires for clinical assessment of canine cognitive dysfunction. Jornal of Veterinary Behavior, Copenhagen, v. 10, n. 6, p. 452-458, 2015. DOI: $10.1016 /$ j.jveb.2015.07.036

SIWAK, C. T.; MURPHEY, H. L.; MUGGENBURG, B. A.; MILGRAM, N. W. Age-dependent decline in locomotor activity in $\operatorname{dogs}$ is environment specific. Physioogy. Behavior, Toronto, v.75, n. 1, p. 65-70, 2002.

SVICERO, J. D.; HECKLER, M. C. T.; AMORIM, R. M. Prevalence of behavioral changes in senile dogs. Revista Ciência Rural, São Paulo, v. 47, n. 2, p. x-x, 2017. DOI: $10.1590 / 0103-8478 \mathrm{cr} 20151645$ 
